\title{
Effect of Rock Phosphate on Nutrient Status and Nut Load of Mature Coconut in South-Western Ghana
}

\author{
E. Andoh-Mensah ${ }^{1}$, A. Addae-Manu ${ }^{2}$, and D. K. Nutsukpo ${ }^{2}$
}

\begin{abstract}
The effect of rock phosphate on mature coconut was evaluated from 2004 to 2010 within the context of low nut yield due to phosphorus deficiency in the acidic soils of South-Western Ghana. A low reactive Togo rock phosphate containing $25.5 \% \mathrm{P}_{2} 0_{5}$ was applied. Three application schedules based on $666 \mathrm{~kg} / \mathrm{ha}$ rock phosphate and a control were evaluated in a Randomized Complete Block Design with five replications. The application schedules were: (a) Bulk application at $4.5 \mathrm{~kg} /$ tree (b) Two-equal-split application at $2.25 \mathrm{~kg} /$ tree in years land 3 (c) Three-equal-split application at $1.5 \mathrm{~kg} /$ tree in years 1,2 and 3. Muriate of potash fertilizer was applied at $2 \mathrm{~kg} /$ tree as basal treatment. Plot size was 0.2 ha comprising 30 trees. Nut load and leaf nutrient status of coconut palms were determined. Rock phosphate led to a significant $(\mathrm{P}<0.01)$ increase in leaf phosphorus and nut yield. It sustained a superior nut load for a 4-year period beginning from year 2 of application to year 5 with average nut gain of 19.0 per tree compared to 4.6 per tree in the control palms. There was no significant $(\mathrm{P}>0.05)$ difference in nut yield and nutrient status between bulk and split methods of rock phosphate application. A value-to-cost ratio of 1.5 was obtained thus indicating the profitability of rock phosphate application in the acidic soils of South-Western Ghana. Coir geotextiles find application in revegetation of slopes by stabilizing the soil through erosion control. It has been found that the longevity of coir geotextiles although highest among all the natural fibres, it is required to last for at least 5 years so as to sustain the vegetation on the slopes for a long term solution. Normally it is found that coir geotextiles lose their 50\% strength in 6 months in contact with soil, therefore it is required to strengthen the coir geotextiles.
\end{abstract}

Key words: Rock phosphate, mature coconut, nut load, nut gain, South-Western Ghana.

\footnotetext{
${ }^{1}$ Oil Palm Research Institute, Coconut Programme, Box 245, Sekondi, Ghana.

${ }^{2}$ Ministry of Food and Agriculture, Department of Crop Services, Box M37, Accra, Ghana.

Corresponding author: E. Andoh-Mensah. E-mail: andomens@yahoo.com
} 


\section{Introduction}

The heartbeat of Ghana's coconut industry is found in the humid areas of South-Western Ghana where soils have been identified to be strongly acidic, heavily leached and deficient in available phosphorus (Issaka et al., 2008). Phosphorus deficiency is an important nutritional problem since the element is one of the major macronutrients required for optimal plant growth and development (Ahuja et al., 2007). In mature coconut, phosphorus deficiency is known to limit nut load response to applied nitrogen and potassium fertilizers (Andoh-Mensah et al., 2003).

The use of conventional superphosphates to address the problem of phosphorus deficiency in humid tropical areas raises the issue of cost effectiveness and sustainability (Ayaga et al., 2006). This is because superphosphates are highly soluble and thus become more vulnerable to phosphorus fixation by Aluminium and Iron oxides (Stevenson, 1986; Hinsinger and Gilkes, 1997; Moody and Bolland, 1999) which dominate the ion exchange complex of humid tropical soils (Sanchez and Uehara, 1980) thus necessitating large applications of high-cost superphosphates to attain satisfactory crop yield (Ayaga et al., 2006).

Unlike superphosphates, rock phosphate is mined naturally and marketed cheaply. It has liming properties which enhance phosphorus uptake in acidic soils (Nishanth and Biswas, 2008) and a slower dissolution rate which leads to a steady release of phosphorus to crops beyond the year of application (Sanchez et al., 1996). The use of rock phosphate was identified as an important component in an integrated nutrition management system under the Soil Fertility Initiative (SFI) of Ghana's Agricultural Services Sub-Sector Investment Programme (AgSSIP) funded by the World Bank.

Based on SFI annual recommendation rate of $127-254 \mathrm{~kg} / \mathrm{ha}$ Togo rock phosphate for coconut density of 100-200 trees/ha, this work sought to evaluate the effect of rock phosphate on nutrient status and nut load of mature coconut in South-Western Ghana.

\section{Materials and Methods}

\section{Study Period and Location}

The study was carried out in the coconut belt of South-Western Ghana over a six-year period (2004-2010) at five locations namely; Adusuazo, Amokwawsuazo, Samenye, Nvelenu and Anwea. Annual rainfall of the locations varied from 1200-1500 mm and distributed bimodally with the major peak in June-July and minor peak in September-October.

\section{Experimental Design}

Five mature coconut farms were selected for the study. The farms were of West African Tall variety aged $20-40$ years and planted at $8.8 \mathrm{~m}$ between rows and $7.7 \mathrm{~m}$ within rows (148 trees/ha). Togo rock phosphate containing $25.5 \% \mathrm{P}_{2} 0_{5}$ and classified as low in reactivity was applied. Three application schedules based on $666 \mathrm{~kg} / \mathrm{ha}$ rock phosphate and a control were evaluated in a randomized complete block design with five replications at five locations. The application schedules were: (1) Bulk application at $4.5 \mathrm{~kg} /$ tree (2) Two-equal-split application at $2.25 \mathrm{~kg} /$ tree in years 1 and 3 (3) Three-equal-split application at $1.5 \mathrm{~kg} /$ tree in years 1,2 and 3 . Plot size was 0.2 ha comprising of 30 trees. Muriate of potash fertilizer was applied at $2 \mathrm{~kg} /$ tree as basal treatment in year 2 . All applications were done in ring form around the palms.

\section{Data Collection and Derivation}

Nuts in bunches of leaf ranks 14, 19 and 24 were counted yearly. The number of nuts in the three bunches were averaged and the mean multiplied by 12 to estimate nut load/ tree/ year (Santos et al., 1996). Soil sampling was done at the onset of the study for chemical analysis. Leaf rank 14 was sampled yearly for leaf nutrient analysis.

\section{Statistical Analysis}

GenStat Discovery Edition 3 statistical software was used for data analysis. Data were subjected to Two-Way Anova (in Randomized Blocks) and comparisons of interest $(\mathrm{C} 1, \mathrm{C} 2$ and $\mathrm{C} 3$ ) were tested using ANOVA contrast. 
$\mathrm{C} 1=$ Rock phosphate application $\left(\mathrm{RP}_{\mathrm{AP}}\right)$ versus control $\left(\mathrm{RP}_{\mathrm{CTL}}\right) ; \mathrm{C} 2=$ Bulk application $\left(\mathrm{RP}_{\mathrm{BU}}\right)$ versus split application $\left(\mathrm{RP}_{\mathrm{SP}}\right)$ of rock phosphate and $\mathrm{C} 3=$ Two-equal-split $\left(\mathrm{RP}_{\mathrm{SP} 2}\right)$ versus threeequal-split $\left(\mathrm{RP}_{\mathrm{SP} 3}\right)$ application of rock phosphate. Comparisons with F-probability $\leq 0.05$ were declared significant.

\section{Value-to-Cost Ratio (VCR) Analysis}

Value cost ratio analysis was used to determine the profitability of rock phosphate application. VCR was calculated as the ratio between the value of effective nut gain due to rock phosphate application and cost of rock phosphate application.

\section{Results}

\section{Chemical Properties of Soil}

The soils at the onset of the study (Table 1) were strongly acidic on the average with high levels of exchangeable acidity $(\mathrm{Al}+\mathrm{H}>0.3$ $\mathrm{cmol} / \mathrm{kg})$ and very low content of available $\mathrm{P}(<$ $10 \mathrm{mg} / \mathrm{kg}$ ). Organic matter and total $\mathrm{N}$ contents ranged from low to moderate levels. Exchangeable cations were extremely low in the case of $\mathrm{Ca}$, moderate with respect to $\mathrm{K}$ and high as regard $\mathrm{Mg}$; exception being Samenye and Adusuazo which had low to moderate exchangeable $\mathrm{Mg}$.

\section{Leaf Nutrient Status}

Apart from leaf P (Table 2), analysis of variance and treatment contrasts of leaf nutrients $(\mathrm{N}, \mathrm{K}, \mathrm{Ca}$ and $\mathrm{Mg})$ were not significant $(\mathrm{P}>0.05)$.

Contrast analysis of leaf $\mathrm{P}$ indicates highly significant $(\mathrm{P}<0.01)$ difference between coconut applied with rock phosphate (leaf P: $0.118 \%$ ) and the control palms (leaf P: $0.113 \%$ ). There was no significant $(\mathrm{P}>0.05)$ difference in leaf $\mathrm{P}$ between coconut that received bulk application of rock phosphate (leaf P: $0.119 \%$ ) and those given split application (leaf P: 0.118\%).

\section{Nut Yield}

Contrast analysis of nut gain (Table 3 ) indicates a highly significant $(\mathrm{P}<0.01)$ difference between coconut applied with rock phosphate and the control palms. There was no significant
$(\mathrm{P}>0.05)$ difference in nut gain between coconut that received bulk application of rock phosphate and those given split application. Nut gain increased significantly $(\mathrm{P}<0.01)$ with time over the study period but interaction between rock phosphate treatment and time was not significant $(\mathrm{P}>0.05)$.

Rock phosphate sustained superior nut yield for a 4-year period beginning from year 2 of rock phosphate application to year 5 with average nut gain of 19.0 per tree compared to 4.6 per tree in the control palms (Table 4).

\section{Value-to-Cost Ratio (VCR) Analysis}

A value-to-cost ratio of 1.5 was obtained (Table 5).

\section{Discussion}

The significant $(\mathrm{P}<0.01)$ increase in leaf phosphorus of coconut palms applied with Togo rock phosphate conformed to expectation. This is because soil factors necessary to enhance phosphorus availability from direct application of rock phosphate were present in the humid coconut belt of South Western Ghana. These factors include low soil $\mathrm{pH}$, low exchangeable $\mathrm{Ca}$ and low P availability (Khasawneh and Doll, 1978; Smyth and Sanchez, 1982; Kanabo and Gilkes, 1988; Chien and Hammond, 1989; Sanyal and De Datta, 1991) as observed at the onset of the study (Table 1). Applied Togo rock phosphate certainly improved the capital stock of phosphorus in the soil system followed by a steady release of the nutrient to coconut palm beyond the year of application (Sanchez et al., 1996).

The superior nut gain in rock phosphateapplied palms could be attributed to the significant $(\mathrm{P}<0.01)$ increase in leaf phosphorus in accordance with a parallel observation in which phosphorus deficiency blocked optimum nut yield in coconut (Andoh-Mensah et al., 2003). The sustenance of superior nut load for a 4-year period in rock phosphate-applied palms probably suggests that continuous application of Togo rock phosphate in bulk at 4-year intervals could possibly maintain a superior nut yield for a longer period in mature coconut barring other 
Table 1. Some chemical properties of the top $20 \mathrm{~cm}$ soil at the five study locations in 2004

\begin{tabular}{|l|c|c|c|c|c|c|c|c|}
\hline Location & $\begin{array}{c}\mathbf{p H} \\
\mathbf{1 : 1}\left(\mathbf{H}_{2} \mathbf{O}\right)\end{array}$ & $\begin{array}{c}\mathbf{O . M} \\
\mathbf{\%}\end{array}$ & $\begin{array}{c}\text { Total N } \\
\mathbf{\%}\end{array}$ & $\begin{array}{c}\text { Ex. Ca } \\
\mathbf{c m o l} / \mathbf{k g}\end{array}$ & $\begin{array}{c}\text { Ex. Mg } \\
\mathbf{c m o l} / \mathbf{k g}\end{array}$ & $\begin{array}{c}\text { Ex. K } \\
\mathbf{c m o l} / \mathbf{k g}\end{array}$ & $\begin{array}{c}\text { Ex. (Al+H) } \\
\mathbf{c m o l} / \mathbf{k g}\end{array}$ & $\begin{array}{c}\text { Avail. P } \\
\mathbf{m g} / \mathbf{k g}\end{array}$ \\
\hline Samenye & 5.2 & 1.5 & 0.11 & 1.74 & 0.27 & 0.36 & 0.35 & 1.32 \\
Amokwaw & 4.5 & 3.2 & 0.17 & 1.74 & 1.47 & 0.26 & 0.55 & 2.30 \\
Nvelenu & 5.2 & 1.0 & 0.07 & 1.87 & 1.20 & 0.21 & 0.40 & 2.66 \\
Anwia & 4.5 & 3.2 & 0.16 & 1.40 & 2.14 & 0.34 & 0.58 & 3.62 \\
Adusuazo & 4.6 & 1.4 & 0.09 & 1.27 & 0.60 & 0.27 & 0.53 & 2.47 \\
\hline \multicolumn{1}{|c|}{ Mean } & 4.82 & 2.04 & 0.12 & 1.60 & 1.14 & 0.28 & 0.48 & 2.47 \\
& & & & & & & & \\
\hline
\end{tabular}

O.M=Organic matter; Ex.=Exchangeable; Avail.=Available

Table 2. Variance and contrast analysis of leaf $\mathrm{N}, \mathrm{P}, \mathrm{K}, \mathrm{Mg}$ and Ca concentrations (\% dry weight) as affected by rock phosphate treatment of mature coconut

\begin{tabular}{|c|c|c|c|c|c|}
\hline Source of variation & Df & $\begin{array}{l}\text { Sum of } \\
\text { Square }\end{array}$ & $\begin{array}{c}\text { Mean } \\
\text { Square }\end{array}$ & $\begin{array}{l}\text { Var. } \\
\text { Ratio }\end{array}$ & $\begin{array}{c}\text { F. } \\
\text { Prob. }\end{array}$ \\
\hline \multicolumn{6}{|l|}{ Rock phosphate treatment } \\
\hline Leaf N & 3 & 0.0228 & 0.0076 & 2.30 & $0.086^{\mathrm{ns}}$ \\
\hline \multicolumn{6}{|l|}{ Contrast } \\
\hline $\mathrm{C} 2: \mathrm{RP}_{\mathrm{BU}}(1.923 \%) v s . \mathrm{RP}_{\mathrm{SP}}(1.894 \%)$ & 1 & 0.0138 & 0.0138 & $\begin{array}{l}2.09 \\
4.18\end{array}$ & $0.054^{\mathrm{ns}}$ \\
\hline $\mathrm{C} 3: \mathrm{RP}_{\mathrm{SP} 2}(1.888 \%) v s . \mathrm{RP}_{\mathrm{SP} 3}(1.901 \%)$ & 1 & 0.0021 & 0.0021 & 0.64 & $0.427^{\mathrm{ns}}$ \\
\hline Leaf $P$ & 3 & 0.0005 & 0.0002 & 4.65 & $0.005^{* *}$ \\
\hline \multicolumn{6}{|l|}{ Contrast } \\
\hline $\mathrm{C} 1: \mathrm{RP}_{\mathrm{AP}}(0.118 \%) v s . \mathrm{RP}_{\mathrm{CTL}}(0.113 \%)$ & 1 & 0.0005 & 0.0005 & 13.82 & $<0.001^{* *}$ \\
\hline $\mathrm{C} 2: \mathrm{RP}_{\mathrm{BU}}(0.119 \%)$ vs. $\mathrm{RP}_{\mathrm{SP}}(0.118 \%)$ & 1 & 0.000004 & 0.000004 & 0.12 & $0.736^{\mathrm{ns}}$ \\
\hline $\mathrm{C} 3: \mathrm{RP}_{\mathrm{SP} 2}(0.118 \%) v s . \mathrm{RP}_{\mathrm{SP} 3}(0.118 \%)$ & 1 & 0.0000 & 0.0000 & 0.00 & $1.000^{\mathrm{ns}}$ \\
\hline Leaf $K$ & 3 & 0.0441 & 0.0441 & 1.74 & $0.169^{\mathrm{ns}}$ \\
\hline \multicolumn{6}{|l|}{ Contrast } \\
\hline $\mathrm{C} 1: \mathrm{RP}_{\mathrm{AP}}(0.986 \%) v s . \mathrm{RP}_{\mathrm{CTL}}(0.980 \%)$ & 1 & 0.0006 & 0.0006 & 0.08 & $0.783^{\mathrm{ns}}$ \\
\hline $\mathrm{C} 2: \mathrm{RP}_{\mathrm{BU}}(1.000 \%) v s . \mathrm{RP}_{\mathrm{SP}}(0.979 \%)$ & 1 & 0.0070 & 0.0070 & 0.83 & $0.367^{\text {ns }}$ \\
\hline $\mathrm{C} 3: \mathrm{RP}_{\mathrm{SP} 2}(1.001 \%) v s . \mathrm{RP}_{\mathrm{SP} 3}(0.952 \%)$ & 1 & 0.0364 & 0.0364 & 4.31 & $0.052^{\mathrm{ns}}$ \\
\hline Leaf Mg & 3 & 0.0132 & 0.0044 & 0.41 & $0.745^{\text {ns }}$ \\
\hline \multicolumn{6}{|l|}{ Contrast } \\
\hline $\mathrm{C} 1: \mathrm{RP}_{\mathrm{AP}}(0.303 \%) v s . \mathrm{RP}_{\mathrm{CTL}}(0.306 \%)$ & 1 & 0.00008 & 0.00008 & 0.01 & $0.933^{\mathrm{ns}}$ \\
\hline $\mathrm{C} 2: \mathrm{RP}_{\mathrm{BU}}(0.301 \%) v s . \mathrm{RP}_{\mathrm{SP}}(0.305 \%)$ & 1 & 0.00015 & 0.00015 & 0.01 & $0.905^{\mathrm{ns}}$ \\
\hline $\mathrm{C} 3: \mathrm{RP}_{\mathrm{SP} 2}(0.321 \%) v s . \mathrm{RP}_{\mathrm{SP} 3}(0.288 \%)$ & 1 & 0.01299 & 0.01299 & 1.22 & $0.275^{\mathrm{ns}}$ \\
\hline Leaf Ca & 3 & 0.0128 & 0.0042 & 1.06 & $0.372^{\mathrm{ns}}$ \\
\hline \multicolumn{6}{|l|}{ Contrast } \\
\hline $\mathrm{C} 1: \mathrm{RP}_{\mathrm{AP}}(0.230 \%)$ vs. $\mathrm{RP}_{\mathrm{CTL}}(0.240 \%)$ & 1 & 0.0019 & 0.0019 & 0.47 & $0.494^{\mathrm{ns}}$ \\
\hline $\mathrm{C} 2: \mathrm{RP}_{\mathrm{BU}}(0.247 \%) v s . \mathrm{RP}_{\mathrm{SP}}(0.236 \%)$ & 1 & 0.0050 & 0.0050 & 1.25 & $0.267^{\mathrm{ns}}$ \\
\hline $\mathrm{C} 3: \mathrm{RP}_{\mathrm{SP} 2}(0.247 \%) v s . \mathrm{RP}_{\mathrm{SP} 3}(0.225 \%)$ & 1 & 0.0059 & 0.0059 & 1.46 & $0.231^{\mathrm{ns}}$ \\
\hline
\end{tabular}

$*=$ Significant at $\mathrm{P} \leq 0.05 \quad * *=$ Significant at $\mathrm{P} \leq 0.01 \quad{ }^{\mathrm{ns}}=$ Not Significant at $\mathrm{P}=0.05 \quad v s=$ Versus 
Table 3. Variance and contrast analysis of nut gain as affected by rock phosphate treatment of mature coconut

\begin{tabular}{|l|r|r|r|r|r|}
\hline \multicolumn{1}{|c|}{ Source of variation } & Df & \multicolumn{1}{|c|}{$\begin{array}{c}\text { Sum of } \\
\text { Square }\end{array}$} & $\begin{array}{c}\text { Mean } \\
\text { Square }\end{array}$ & \multicolumn{1}{c|}{$\begin{array}{c}\text { Var. } \\
\text { Ratio }\end{array}$} & \multicolumn{1}{c|}{$\begin{array}{c}\text { F. } \\
\text { Prob. }\end{array}$} \\
\hline Rock phosphate treatment & & & & & \\
Nut gain per tree & 3 & 1759.24 & 586.41 & 6.92 & $<0.01^{* *}$ \\
Contrast & 1 & 1528.64 & 1528.64 & 18.04 & $<0.01^{* *}$ \\
$\mathrm{C} 1: \mathrm{RP}_{\mathrm{AP}} v s . \mathrm{RP}_{\mathrm{CTL}}$ & 1 & 134.20 & 134.20 & 1.58 & $0.213^{\mathrm{ns}}$ \\
$\mathrm{C} 2: \mathrm{RP}_{\mathrm{BU}} v s . \mathrm{RP}_{\mathrm{SP}}$ & 1 & 96.41 & 96.41 & 1.14 & $0.290^{\mathrm{ns}}$ \\
$\mathrm{C} 3: \mathrm{RP}_{\mathrm{SP} 2} v s . \mathrm{RP}_{\mathrm{SP} 3}$ & 3 & 6715.11 & 2238.37 & 26.41 & $<0.01^{* *}$ \\
Time & 9 & 464.48 & 51.61 & 0.61 & $0.785^{\text {ns }}$ \\
Nut gain per tree .Time & & & & & \\
\hline
\end{tabular}

$*=$ Significant at $\mathrm{P}<0.05 \quad * *=$ Significant at $\mathrm{P}<0.01 \quad{ }^{\mathrm{ns}}=$ Not Significant at $\mathrm{P}=0.05 \quad$ vs $=$ Versus

Table 4. Nut gain per tree over the study period

\begin{tabular}{|l|c|c|c|c|c|c|}
\hline \multicolumn{1}{|c|}{ Treatment } & Year 1 & Year 2 & Year 3 & Year 4 & Year 5 & Year 6 \\
\hline Rock phosphate & -1.6 & 18.8 & 20.4 & 20.3 & 16.6 & 3.3 \\
Control & -4.4 & 5.2 & 8.8 & 6.6 & -2.2 & -8.8 \\
\hline
\end{tabular}

Mean of year 2-5: Rock phosphate $=19 ;$ Control $=4.6$

Table 5. Value-to-cost ratio analysis of rock phosphate (RP) application

\begin{tabular}{|l|l|}
\hline No. & \multicolumn{1}{|c|}{ Item } \\
\hline 1. & $\begin{array}{l}\text { Cost of RP application } \\
\text { Cost of RP per hectare }=\text { US } \$ 466.20 \\
\text { Cost of labour per hectare }=\text { US } \$ 111.00 \\
\text { Cost of RP application per hectare }(466.20+111.00)=\text { US } \$ 577.20\end{array}$ \\
2. & $\begin{array}{l}\text { Value of effective nut gain over a four-year response period } \\
\text { Total nut gain per hectare over a 4-year response period in RP palms }=11,248 \\
\text { Total nut gain per hectare over a 4-year response period in control palms }=2,723 \\
\text { Effective nut gain per hectare }(11,248-2,723)=8,525 \\
\text { Farm gate price per nut = US\$ 0.10 } \\
\text { Value of effective nut gain per hectare }(8,525 \times 0.10)=\text { US\$ 852.50 } \\
\text { Value-to-cost ratio (VCR) } \\
\text { Value of effective nut gain/ Cost of RP application }(852.50 / 577.20)=1.5\end{array}$ \\
\hline
\end{tabular}


nutrient limitation especially potassium. The absence of significant $(\mathrm{P}>0.05)$ difference in performance between coconut that received bulk application of rock phosphate and those given split application seemed to support the advocacy for bulk application of rock phosphate for soil fertility 'recapitalization' due to its long-term residual effectiveness (Sanchez et al., 1996).

A value-to-cost ratio of 1.5 was an indication of the profitability of rock phosphate application in mature coconut trees of South Western Ghana.

\section{Conclusion}

Application of Togo rock phosphate in mature coconut palms of south western Ghana at $4.5 \mathrm{~kg}$ per tree led to a significant $(\mathrm{P}<0.01)$ increase in leaf phosphorus and nut yield. Rock phosphate sustained a superior nut load for a four-year period beginning from year 2 of application to year 5 with average nut gain of 19.0 per tree compared to 4.6 per tree in the control palms. There was no significant $(\mathrm{P}>0.05)$ difference in performance between coconut that received bulk application of rock phosphate and those given split application. A value-to-cost ratio of 1.5 was obtained thus indicating the profitability of rock phosphate application in the acidic soils of South-Western Ghana.

\section{Acknowledgement}

The authors hereby acknowledge the financial assistance given under the Agricultural Services Sub-sector Investment Project (AgSSIP) funded by the World Bank. They also wish to express their gratitude to the following staff of the Oil Palm Research Institute Coconut Programme: Messrs Richard Nkrumah, Joseph Martin-Bannerman, Elizabeth Adjei, John Ediyie and Ben Baidoo for their immense technical support.

\section{References}

Andoh-Mensah, E., Bonneau, X., Nuertey, B.N. and Dery S. K. 2003. Effect of mineral nutrition on coconut yield and fruit composition of mature coconut palms in the coastal belt of Western Region of Ghana: Preliminary Studies. CORD Vol. XIX No. 2, pp 11-19.

Ahuja, A., Ghosh, S. B. and D'Souza, S. F. 2007. Isolation of a starch utilizing, phosphate solubilizing fungus on buffered medium and its characterization. Bioresource Technology 98: 3408-3411.

Ayaga, G., Todd, A. and Brookes, P. C. 2006. Enhanced biological cycling of phosphorus increases its availability to crops in low-input sub-Saharan farming systems. Soil Biology \& Biochemistry 38:81- 90 .

Chien, S. H. and Hammond, L. L. 1989. Agronomic effectiveness of partially acidulated phosphate rock as influenced by soil phosphorus-fixing capacity. Plant and soil 120, 159-164.

Hinsinger, P. and Gilkes, R. J. 1997. Dissolution of rock phosphate in the rhizosphere of five plant species grown in an acid, P-fixing mineral substrate. Geoderma 75: 231-249.

Issaka, R. N., Senayah, J. K., Andoh-Mensah, E. and Ennin, S. A. 2008. Characteristics of benchmark soils for coconut production in parts of Western and Central Regions of Ghana. CSIR-Soil Research Institute Technical Report No. 278. pp. 1-29.

Kanabo, I. A. K. and Gilkes, R. J. 1988. The effects of moisture regime and incubation period on the dissolution of North Carolina phosphate rock in soil. Australian Journal of Soil Research 26, 153-163.

Khasawneh, F. E. and Doll, E. C. 1978. The use of phosphate rock for direct application to soils. Advances in Agronomy 30, 159206.

Moody, P.W., Bolland, M.D.A., 1999. Phosphorus. In: Peverill, K.I., Sparrow, L.A., Reuter, D.J. (Eds.), Soil Analysis: An Interpretation Manual. CSIRO Publishing, Collingwood, Australia, pp. 187-220. 
Nishanth, D. and Biswas, D. R. 2008. Kinetics of phosphorus and potassium release from rock phosphate and waste mica enriched compost and their effect on yield and nutrient uptake by wheat (Triticum aestivum). Bioresource Technology 99:3342-3353.

Sanchez, P. A. and Uehara, G. 1980. Management considerations for acid soils with high phosphorus fixation capacity. In: Khasawneh, F.E. et al. (eds) The role of phosphorus in agriculture. American Society of Agronomy, Madison, Wisconsin, pp. 471-514.

Sanchez, P.A., Izac, A.M., Valencia, A. and Pieri, C. 1996. Soil fertility replenishment in Africa. A concept note. In: Breth, S.A. (Ed.), Achieving Greater Impact from Research Investments in Africa. Sasakawa Africa Association.
Santos, G. A., Batugal, P. A., Othman, A., Baudouin, L. and Laboisse, J. P. (eds). 1996. Manual on standardized research techniques in coconut breeding. IPGRIAPO, Serdang, Malaysia.

Sanyal, S. K. and De Datta, S. K. 1991. Chemistry of phosphorus transformations in soils. Advances in Soil Science 16, 3160.

Smyth, T. J. and Sanchez, P. A. 1982. Phosphate rock dissolution and availability in Cerrado soils as affected by phosphorus sorption capacity. Soil Science Society of America Journal 53, 456-459.

Stevenson, F.J., 1986. Cycles of Soil. Wiley, New York. 